\title{
9. Political Parties and the 2007 National Election: Alignment to Reform?
}

\author{
Alphonse Gelu
}

\section{Introduction}

Papua New Guinea's parliamentary democracy took a new turn in the period 2002-2007, by maintaining continuity in the political regime. This was probably attributable to an important reform that was instituted by the Morauta government in 2001, namely the Organic Law on the Integrity of Political Parties and Candidates (OLIPPAC). While this is a significant development, some sceptics are not comfortable with several aspects of the reform, such as the provisions for the formation of government and the continued success of independent candidates in the elections.

The 2007 election was the second in Papua New Guinea to be conducted under the OLIPPAC, and the parliament of 2002-2007 was the first in which a postindependence government served a full term in office. In 2007 the incumbent prime minister, Sir Michael Somare, as leader of the National Alliance party, was returned to office.

This chapter asks: what role did the ambitious political reforms, aimed at strengthening political parties, play in delivering this result? And how have Papua New Guinea's loosely knit and flexible political parties changed under the new institutional arrangements?

There is a substantial literature on the role of political parties in Papua New Guinea (Wolfers 1970; Stephen 1972; Hegarty 1979; King 1989; May 1984, 2002, 2006; Reilly 1999; Anere 2000; Okole 2006) and a general agreement that political parties are highly fragmented and have remained weak in terms of ideology and organization. They are essentially parliamentary factions and have not provided a link between government and society.

Papua New Guinea has always had a multi-party system, with a record of 43 political parties contesting the 2002 national elections and 34 contesting in 2007. From 1977 to 2002, the number of parties contesting the elections was between five and ten. Despite the proliferation, parties remain detached from the 
people. Like parties in mature democracies such as Australia and New Zealand, Papua New Guinea parties develop policy platforms, endorse candidates, and campaign to attract support for their candidates. However, their support base is limited and the large number of independents winning seats is an indication that the people do not vote along party lines.

\section{Political parties in the 2007 election}

A total of 2759 candidates contested the 2007 election with 1478 standing as independents and 1281 endorsed by political parties. A total of 34 parties contested the 2007 elections. This number was a decrease from the 2002 elections. The number of candidates endorsed by parties ranged from 91 by the National Alliance to 1 by the National Front Party. Those which endorsed more than 50 candidates were National Alliance (91), New Generation Party (90), Pangu (84), People's Progress Party (72), PNG Party (61) and Peoples National Congress (51). People's Action Party endorsed 48.

\section{Campaign styles by political parties}

As in the previous elections, political parties began their preparations early, in 2006. The process started with the different parties formulating their policies and holding party conventions to sort out internal matters relating to leadership, membership and party policies.

The campaign in 2007 was not as intense as those of past elections. There was less of the fanfare and feasting that was characteristic of previous elections, though attempts were made to buy the loyalty of voters through the distribution of money and goods, especially in the Highlands. Sir Michael Somare was accused of giving out K600 million for infrastructure projects in his electorate (East Sepik Provincial). The OLIPPAC authorizes the payment of K10,000 for each party-endorsed MP before the end of the parliamentary term and this favours the larger parties. It is generally accepted, also, that the parties in government enjoy greater access to funding for local projects, giving those parties a further advantage.

However, the outlay of money did not guarantee success. A notable example was in the Western Highlands Provincial contest, where 25 candidates stood against the sitting member, Paias Wingti, a former prime minister once named as the richest man in the Pacific. They included a young unknown candidate, Tom Olga, a former student at the University of Papua New Guinea. Olga started his campaign soon after the 2002 election. With a very small budget, he walked from village to village, sleeping in the villages and talking with the people. His 
style of campaigning made him popular, and despite Wingti's strong showing in the first preference count, Olga took the lead in the count of preferences and he was eventually declared the winner. Several high-profile candidates, including Bart Philemon in Lae Open, Sir Joe Tauvasa in West New Britain Provincial and Powes Parkop in National Capital District, also ran relatively lowcost campaigns, with mixed results. Philemon won his seat but Tauvasa, despite an early lead, came second to National Alliance candidate Peter Humphreys, who spent thousands of kina on his campaign. For Parkop, it was a tough battle against the incumbent, Wari Vele, governor of National Capital District who had won the seat in a controversial by-election in 2006. Vele, a successful businessman, ran an expensive campaign with advertisements on television and a theme song performed by popular artist Moses Tau, which referred to Vele as 'lightning and thunder'. Patrkop told the people he had no money to spend but encouraged them to vote for good leadership. He won comfortably.

Several candidates campaigned on a platform of good leadership, integrity, and promotion of good governance through transparency, accountability and maintenance of the rule of law. The election of Parkop, and the re-election of Dame Carol Kidu in Moresby South and Sir Mekere Morauta in Moresby NorthEast, suggested that, at least in the national capital, such a platform had some appeal to voters in 2007.

The lower intensity of campaigning might be ascribed to the use of limited preferential voting, which encourages alliances between the different parties and candidates. In some electorates, communities invited parties and candidates to come together and present their policies in a combined rally. Candidates and parties carried out more extensive campaigns than in the past, in order to collect preference votes. Candidates ventured into enemy territories, something that seldom happened in previous elections.

Radio was the most common means of transmitting information about parties and candidates. Newspapers were also used by parties which could meet the high cost of printing campaign materials. Television was used by a few parties.

Most of the political party campaigns kicked off soon after their party conventions. The first political party to use the media in its campaign was Pangu Pati, whose parliamentary leader, Sir Rabbie Namaliu, announced the four main policy pillars of the party. This was followed by the ruling National Alliance party, whose campaign preparations were interrupted by a struggle over the party's leadership. This was settled when Bart Philemon, the deputy leader of the party, was expelled, allowing Sir Michael Somare to continue his leadership of the party. Soon after his expulsion (which was formally announced in April 2007), Philemon began preparations for the launch of a new party, the New Generation Party. 
The New Generation Party staged a strong campaign against the ruling National Alliance, with Philemon pushing for policies that were different from those of the National Alliance. Philemon, who was a minister in the Somare government of 2002-2007, was not happy with some of the decisions made by the government, especially with regard to financial management; he referred specifically to a 'US bond issue', which he had refused to endorse as treasurer because he felt that the transaction would not be in the best interests of the country (see PostCourier 13 March 2007).

Other parties also criticized decisions and actions of the National Allianceled government, including the PNG Party headed by Sir Mekere Morauta, the People's Party headed by Peter Ipatas, the People's Progress Party led by Byron Chan, and the People's Labour Party headed by Peter Yama. Yama declared an allout war against the National Alliance; however, he lost the Madang Provincial seat, which was won by Sir Arnold Amet, a National Alliance candidate.

The 2007 campaign became personal when the parliamentary leader of the PNG Country Party, Jamie Maxtone-Graham, was publicly accused by the president of the National Alliance, Simon Kaiwi, of not having land, or 'even a toilet', in the electorate that he represented. This represented a new style of campaigning in Papua New Guinea, where parties and their executives have seldom said personal things against one another in the media.

During the campaign period, the New Generation Party was to have launched its campaign in Wewak, the provincial capital of East Sepik Province, the prime minister's electorate, but was told by the police that they did not have authorization to do so. This was another shift in campaigning style.

Alliances between the different parties slowly emerged during the campaign period of March to June. The most salient was that between the PNG Party and the New Generation Party, whose leaders, Sir Mekere Morauta and Bart Philemon, respectively, publicly announced their alliance and commented on the need for like-minded parties to come together to form a coalition government. The National Alliance and its coalition partners also maintained their commitment to each other going into the election. Some parties that remained broadly neutral, such as the People's National Congress headed by Peter O'Neill, People's Party headed by Peter Ipatas, People's Democratic Movement headed by Paias Wingti, Rural Development Party headed by Moses Maladina, and Melanesia Liberal Party headed by Dr Allan Marat, eventually joined the National Alliance after the election, despite being dumped at some stage as coalition partners in the 2002-2007 parliament. Marat, $\mathrm{O}^{\prime}$ Neill and Maladina were all deputy prime ministers at some point in the Somare government of 2002-2007 and all decided to join Somare after the 2007 election. This was criticized by Sir Julius Chan, who made a comeback in 2007. Sir Julius decried the continuous breaking of 
coalition agreements between the National Alliance party and its partners: 'We helped put Somare in the highest office of the land each time with a clear coalition pact, sadly each time we signed the memorandum of understanding, it was broken before the ink got dry'. He vowed the People's Progress Party would not get into bed with parties it was not comfortable with, echoing sentiments New Generation Party leader Philemon had expressed (Post-Courier 10 April 2007).

Pangu Pati was the only major party that made no commitment going into the 2007 election. As a coalition partner in the Somare-led government of 20022007, it was envisaged that it would go with the National Alliance; however, there were also signs that its parliamentary leader, Sir Rabbie Namaliu, was talking with Sir Mekere Morauta and Bart Philemon. Namaliu made a public statement that Pangu would go with like-minded parties-language that was also used by Morauta and Philemon.

To maintain alliances between the parties, agreements were made in some electorates not to put up candidates against sitting members of coalition partners. This was evident in East Sepik Regional, for example, where a number of parties decided not to put up candidates against Sir Michael Somare. However, this arrangement looked suspect in some electorates, where parties that gave an undertaking not to put up candidates allegedly supported independent candidates. One such example was in Kokopo, where a number of parties decided not to put up candidates against Sir Rabbie Namaliu, but it was later revealed that the eventual winner was supported by the National Alliance. Namaliu, who calmly accepted his defeat, later expressed his disappointment to the media. The practice of putting up 'undercover' candidates also contravenes the spirit of OLIPPAC, specifically s. 55, which states that parties should not endorse more than one candidate in an electorate - though this is very likely to happen where parties agree not to contest against sitting members who are vulnerable to defeat.

Leaders of various parties travelled the country campaigning for their candidates. Sir Michael Somare, leader of the National Alliance, toured almost all of the provinces, hiring helicopters to travel to very remote areas. Peter Yama, leader of the People's Labour Party, also toured widely, having declared war against the ruling National Alliance, which he said he would 'kill' in the election. (Yama, the sitting member for Usino-Bundi, decided to contest the Madang Provincial seat in 2007, but was defeated by former chief justice Sir Arnold Amet, a National Alliance candidate.) Pangu leader Sir Rabbie Namaliu, PNG Party leader Sir Mekere Morauta, Peter Ipatas, leader of the People's Party, and Bart Philemon, leader of the New Generation Party also travelled the country campaigning for their party candidates. Political rallies were organized in the 
towns and districts they visited and promises were made. Attacks were made on other parties; the National Alliance was at the receiving end of most criticism, as was to be expected since it was the leading party in the coalition government.

\section{Party politics}

With a large number of parties contesting, it was anticipated that there would be a wide range of policies from which voters could choose. However, looking at the policies in areas such as education, the economy, law and order, infrastructure, and resource development, many of the parties tend to agree on what they would do if they were in government. Nevertheless, some party policies were quite comprehensive and there was a number of differences. This was an interesting development since in the past parties have been criticized for the similarity of their policies.

In an initiative carried out by the National Research Institute (NRI) in partnership with the various media organizations, a public seminar series was organized in early 2007 to allow political parties to present their policies. ${ }^{1}$ The NRI initiative was an attempt to break the tradition of voting along tribal lines and encourage voters to elect candidates on party policies (Post-Courier 7 March 2007). Despite the popularity of the program, only eight of the 34 parties responded and presented their policies. ${ }^{2}$ Five of the eight were either new parties or old parties attempting a comeback. ${ }^{3}$

In addition to the seminar series, the NRI offered to assist political parties who requested help in framing their policies. Only two parties responded, Pangu and the People's Party. As a result, these two parties had coherent policies and outlined clearly what they wanted to achieve if they were in government.

The seminar series demonstrated that despite some similarities, party policies have become more detailed and comprehensive. This is an encouraging new development.

Pangu, which was the first party to start its campaign and announce its policies, placed emphasis on income generation for the rural population, good

\footnotetext{
1 The presentations were recorded and broadcast by the Karai Radio of the National Broadcasting Corporation, which was a key partner in the seminar series.

2 These included Pangu Pati, New Generation Party, Melanesian Liberal Party, National Party, PNG Country Party, People's Freedom Party, PNG Party, and People's National Congress. The presentation of policies was made by the party leaders, except in the case of Pangu, which was represented by its general secretary, Moses Taian.

3 Two parties, the Country Party and the National Party, were formed in the 1970s and were trying to make a comeback in the 2007 election. Between them, they won only two seats and both were in the camp that eventually formed the government.
} 
governance with zero tolerance of corruption, and infrastructure development. It also wanted to increase the size of the defence force (Post-Courier 23 March 2007). The last of these was initiated by former Papua New Guinea Defence Force commander, Jerry Singirok, ${ }^{4}$ who contested the Sumkar Open seat (in which he was runner-up). As the oldest party in the country, Pangu sought to project itself as a new party with new ideas, policies and leadership. This emphasis was important for Pangu because many people have come to regard it as an old party with outdated policies.

The New Generation Party, formed shortly before the election, presented a detailed list of policies. Its emphasis was on good economic management, public sector reform, and a shift in foreign policy. According to Bart Philemon, 'Anybody who talks about doing away with overseas aid at the moment doesn't really understand; they are kidding themselves' (Post-Courier 30 March 2007). The party was accused of being a friend to Australia; its foreign policy was in sharp contrast to that of the National Alliance, which displayed anti-Australian sentiments in many of its public engagements. The New Generation Party put forward a sound plan for governance reform, which included the establishment of a commission to fight corruption, audit of units in all government agencies, a performance-based management system for departmental heads, and a strict code of professional ethics for public office holders. The New Generation Party took a strong stance against corruption and graft at all levels of government and civil society and advocated for transparency and accountability in all aspects of public administration (Post-Courier 19 February 2007). Party policy specifically outlined how this was to be achieved.

The PNG Party, under the leadership of Sir Mekere Morauta, emphasized sound economic management, good governance, prudent leadership, and service delivery to the people. The PNG Party has attracted many educated Papua New Guineans. Morauta has had a record for instituting processes of good governance and he campaigned on this record in the 2007 election. He also proposed contracting out services, such as pharmaceuticals distribution which has been heavily affected by corruption. His lone fight in parliament to amend the National Capital District Commission Act to get rid of corruption was admired by many and the fact that he retained his seat by a big margin was an indication that voters in his electorate supported his fight against corruption. Morauta accused the National Alliance-led government of doing virtually nothing (Post-Courier 5 March 2007). The PNG Party was also the only party that acknowledged the dangers posed by HIV/AIDS and pledged to fight the epidemic.

4 Singirok, a retired general, was a key figure in the Sandline Crisis of 1997. 
The People's National Congress, under the leadership of Peter O'Neill, also emphasized good economic management and called for a review of foreign policy. It advocated the abolition of provincial governments and the establishment of district authorities, reducing government to two tiers instead of three, and called for a bicameral legislature.

Of the smaller parties, the Country Party under Jamie Maxtone-Graham emphasized rural development through alternative means of transportation, agriculture, and income generation. The Melanesian Liberal Party, led by Dr Allan Marat, called for the use of Christian principles in governing the country, as well as supporting the creation of microfinance credit schemes to assist the rural people to develop small agricultural projects; but the Melanesian Liberal Party's most radical policy was a proposal to give 100 percent ownership to the landowners of all the mining, forestry and fisheries projects in the country. The People's Freedom Party, under Moses Murray, emphasized justice and technical education for the young; party policy was that leaders convicted under the Leadership Code should be banned from politics for life. The People's Freedom Party proposed a similar scheme to the National Party's national youth scheme. The National Party proposed to reintroduce the Village Services Scheme and improve service delivery. The People's Party of Enga governor, Peter Ipatas, stated that the law and order situation must be a priority for any government; tribal fights and other law and order problems had hampered development and if elected to government he would apply zero tolerance of violence and would improve the conditions of the police by addressing issues of wages and housing.

The National Alliance, as the ruling party, campaigned on its track record in office. According to the party, it had achieved a lot in the five years since 2002. When it assumed office, the currency was at an all-time low; foreign reserves were at a low K200 million; government infrastructure (roads, bridges, health centres and hospitals) $)^{5}$ were in poor state; state businesses such as PNG Power, Post PNG, Telikom and Air Niugini were on the brink of collapse. All these were because of poor government decisions and overspending by preceding governments. Since the National Alliance had come into office, the kina had climbed back up to 31 cents against the US dollar, foreign reserves had gone up to K5 billion, government infrastructure was undergoing major rehabilitation, and state enterprises were posting huge profits, and people were seeing real economic growth (Post-Courier 5 March 2007). On its campaign trail, Somare's National Alliance reportedly distributed millions of kina to provinces for various projects. This was criticized by other parties as a tactic to gain support.

5 Despite boasting about improvements in hospitals, between 2002 and 2007 the Angau Hospital in Lae faced closure several times due to lack of drugs and maintenance, and the Boram Hospital in Sir Michael's electorate faced severe drug shortages. 
The other parties in the National Alliance-led government, such as the People's Action Party, United Party, United Resources Party and Melanesian Alliance, also based their policies and campaigns on their record in government.

\section{Results of the 2007 election}

After the first declaration, in Manus, it quickly became apparent that the National Alliance would outperform the other parties. The National Alliance was not only winning seats through its endorsed candidates but was picking up independent candidates who were declared winners in their electorates (see Table 9.1). The National Alliance was criticized in the media especially for the use of the government owned Kumul Aircraft to collect winning candidates throughout the country (Post-Courier 31 July 2007, letter to the editor).

The success of the National Alliance may be attributed, first, to the popularity and experience of its leader, Sir Michael Somare. Despite his age, Sir Michael was at the centre of the campaign for his party and his popularity was evident throughout the country. Huge turnouts greeted him wherever he spoke. Secondly, the party's organization was better than that of other parties. Wherever Somare travelled, he was accompanied by the deputy party leader of the region and this proved effective in the election. The success of the National Alliance was shared by its coalition partners; a good number of ministers from the National Alliance and its coalition partners retained their seats. The exceptions were Bire Kimisopa in Goroka Open and Sam Akoitai in Central Bougainville Open.

The losers in the 2007 election were Pangu Pati and the New Generation Party. The leaders of these two parties are from the generation after Sir Michael Somare. Despite the parties endorsing 174 candidates between them (Pangu 84 and New Generation Party 90), Pangu managed to win only five seats and New Generation Party four with one independent candidate joining the party later. It became even worse for Pangu when its leader, Namaliu, lost his seat in Kokopo.

Of the 34 parties contesting, only 21 won seats. Many of these were new and small and did not have an established party organization or any clear policies; some of them were single-issue parties.

Eight party leaders lost their seats. The most notable (and to most, surprising) of these was Sir Rabbie Namaliu, leader of Pangu Pati and a former prime minister. Another former prime minister, Paias Wingti, also lost his seat. Other party leaders to lose their seats included Hami Yawari (Conservative Party), Michael Mas Kal (National Party), Moi Avei (Melanesian Alliance), Peter Yama (People's Labour Party), Bire Kimisopa (United Party), and Sam Akoitai (United Resources Party). 
Election 2007: The Shift to Limited Preferential Voting in Papua New Guinea

Table 9.1: Political parties in the 2007 election

\begin{tabular}{|c|c|c|c|c|}
\hline Name of party & $\begin{array}{l}\text { Parliamentary party } \\
\text { leader (pre-election) }\end{array}$ & $\begin{array}{c}\text { Number of } \\
\text { candidates } \\
\text { endorsed }\end{array}$ & $\begin{array}{c}\text { Number } \\
\text { of seats } \\
\text { won }\end{array}$ & $\begin{array}{c}\text { Independent } \\
\text { candidates } \\
\text { joining parties }\end{array}$ \\
\hline Pangu Pati & Sir Rabbie Namaliu & 84 & 5 & - \\
\hline PNG Labour Party & Bob Danaya & 14 & 1 & - \\
\hline People's Progress Party & Byron Chan & 72 & 4 & 1 \\
\hline People's National Congress & Peter O’Neill & 51 & 5 & 1 \\
\hline PNG Country Party & $\begin{array}{l}\text { Jamie Maxtone- } \\
\text { Graham }\end{array}$ & 41 & 2 & - \\
\hline People's Labour Party & Peter Yama & 46 & 2 & - \\
\hline United Party & Bire Kimisopa & 45 & 2 & - \\
\hline National Alliance & Sir Michael Somare & 91 & 27 & 13 \\
\hline PNG National Party & Michael Mas Kal & 49 & 1 & - \\
\hline PNG Party & Sir Mekere Morauta & 61 & 8 & - \\
\hline Christian Democratic Party & Dr Bahanare Bun & 22 & - & - \\
\hline United Resources Party & Sam Akoitai & 25 & 5 & 1 \\
\hline People's Action Party & Gabriel Kapris & 48 & 6 & - \\
\hline People's Freedom Party & na & 10 & - & - \\
\hline People's First Party & Luther Wenge & 23 & 1 & - \\
\hline PNG First Party & na & 25 & - & - \\
\hline PNG Green Party & na & 3 & - & - \\
\hline Yumi Reform Party & na & 18 & - & - \\
\hline People's Heritage Party & Clement Nakmai & 9 & - & - \\
\hline National Front Party & na & 1 & - & - \\
\hline People's Resources Awareness Party & na & 10 & - & - \\
\hline Melanesian Alliance & Sir Moi Avei & 23 & 1 & - \\
\hline Melanesian Liberal Party & Dr Allan Marat & 17 & 2 & - \\
\hline People's Democratic Movement & Paias Wingti & 54 & 5 & - \\
\hline New Generation Party & Bart Philemon & 90 & 4 & 1 \\
\hline Star Alliance Party & na & 72 & - & - \\
\hline People's Party & Peter Ipatas & 67 & 3 & - \\
\hline Rural Development Party & Moses Maladina & 56 & 3 & - \\
\hline PNG Conservative Party & Hami Yawari & 59 & 1 & - \\
\hline Mapal Levites Party & na & 8 & - & - \\
\hline True Party & na & 21 & - & - \\
\hline Pan Melanesian Congress & unknown & 9 & - & - \\
\hline National Conservative Party & na & 10 & - & - \\
\hline National Advance Party & na & 47 & 1 & - \\
\hline Independents ${ }^{a}$ & na & 1478 & 20 & 3 \\
\hline Total & & 2759 & 109 & 20 \\
\hline
\end{tabular}

a From the total of 20 independent candidates, only three remained independent. One of these three, James Yali, a former National Alliance MP (who was serving a gaol sentence at the time of the election but was appealing against the conviction) had his win annulled soon after the election. The seat is now held by a member of the National Alliance. 
It is not uncommon in Papua New Guinea elections for leaders to lose their seats, and parties often disappear when their leaders lose. After the election, the National Advance Party amalgamated with People's Action Party. Amalgamation is allowed under the OLIPPAC, and it can bring like-minded parties together.

\section{The Organic Law on the Integrity of Political Parties and Candidates}

The 2007 election was the second to be held after the passage of the OLIPPAC and the first following a full parliamentary term under OLIPPAC. The new law was intended primarily to develop and strengthen the party system in Papua New Guinea. It makes it a legal requirement to register parties as legal entities under the Associations Incorporation Act and with the Office of the Registrar of Political Parties, and authorizes limited public funding for political parties.

It also lays down conditions to maintain discipline within the party system. It has been well documented that in Papua New Guinea lack of party discipline and loyalty had led to instability within the parliamentary system. The existence of a 'yo-yo' culture, with members changing political party affiliation and parties changing coalition partners, contributed to the fall of governments through votes of no confidence.

By limiting the ways MPs can vote on important measures, and imposing penalties if they transgress (ss. 77-80), the OLIPPAC makes it difficult for MPs to withdraw their support from a party. This helped Sir Michael Somare and his government stay in office for the full five years from 2002 to 2007.

\section{Formation of government}

Under the OLIPPAC, 'the Electoral Commission shall advise the Head of State of the registered political party which has endorsed the greatest number of candidates declared elected in the election, and the Head of State, acting with, and in accordance with, the advice of the Electoral Commission, shall invite that registered political party to form the government in accordance with this section' (s. 63(1)).

The National Alliance won the most seats (27) and was accordingly invited to form government. Since the National Alliance lacked an absolute majority, however, as in previous post-election situations, a process of coalition formation began. 
In the expectation of forming government, the National Alliance and its partners met in Kokopo to put a coalition together by courting other parties and, most importantly, independent candidates, ${ }^{6}$ with offers of ministerial posts, appointments to parliamentary committees and other rewards. Of the 20 successful independent candidates, 13 joined the National Alliance bringing the party's total number of MPs to 40. The parties in the Kokopo camp signed a pledge to remain loyal to the National Alliance and its leadership.

Although the OLIPPAC rules out multiple endorsement of candidates by a party in the same electorate, there were allegations of multiple or 'hidden' endorsements (generally referred to as 'undercover candidates'), but this was difficult to prove. Such a practice was probably inevitable where parties had agreed not to put up candidates against coalition partners, but were not confident the endorsed candidates would be returned.

In the weeks leading up to the election of the prime minister, a rival camp emerged, headed by Bart Philemon and Sir Mekere Morauta, at the Hideaway Hotel in Port Moresby and an open invitation was sent out to other parties and independent candidates to join the camp (Post-Courier 26 July 2007). In media statements, both the Kokopo camp and the Hideaway camp expressed confidence in their ability to form government (Post-Courier 2 August 2007). ${ }^{7}$ The Hideaway camp teamed up with the People's Progress Party and nominated Sir Julius Chan as its candidate for prime minister.

On 6 August, the National Alliance was formally invited by the governorgeneral to form government and a week later, on 13 August, 86 MPs voted for Somare as prime minister (three fewer than in 2002). Apart from his National Alliance, Somare was supported by 13 other parties from the Kokopo camp. The Hideaway camp managed only 21 MPs. The election of Somare made him the first MP to occupy the office of prime minister on four separate occasions (1975-1980, 1982-1985, 2002-2007, and 2007-).

\section{Independent candidates}

The OLIPPAC does not encourage candidates to remain independent: there are no financial benefits for independent MPs and under s. 86(1) independent candidates can seek membership of parties once they are elected into parliament.

6 Section 69(2) of the OLIPPAC states: A Member of Parliament elected at a general election without endorsement by a registered political party may join a registered political party at any time after the return of the writs and before the first election by the Parliament of a Speaker following the date of the return of the writs in that general election provided that that registered political party had endorsed candidates at that general election'.

7 Sections 63(7), (8) provide that in the event that the party that is invited by the governor-general to form the government cannot muster a simple majority, then the Standing Orders of parliament will be applied and another vote taken. 
The success of independent candidates compared to party-endorsed candidates is still high. The National Alliance won 27 seats, but independent candidates won 20, compared with the next most successful party, PNG Party, with 8. Independent candidates have come to play a central role in the formation of the government, with the National Alliance picking up 13 additional MPs after they were declared. In 2007 only three remained independent.

Elsewhere I have recommended a review of the OLIPPAC to impose guidelines on independent candidates (see Gelu in Post-Courier 15 August 2007). Independent candidates should remain independent throughout their term in parliament and should not take any part in the formation of government. The formation of the government should be left to parties; this would encourage parties to work hard to get more votes and more seats in elections. All efforts should now focus on how the party system can be strengthened.

\section{'One-man' parties}

After the passing of the OLIPPAC, political parties proliferated. Forty-three contested in 2002 and 34 in 2007. In the 2007 election, however, seven parties endorsed fewer than 10 candidates, with one endorsing three candidates and another only one. When the outcome of the election had been decided, 10 of the 21 successful parties had only one or two MPs (four had two MPs, six had one); 13 parties were without parliamentary representation, but still exist outside parliament. Many of the latter lack genuine platforms and have no support base or financial resources to carry out successful campaigns. Some commentators believe that the OLIPPAC has led to an increase in the number of parties and that it should now find ways to limit the number of parties contesting the election.

MPs who have been expelled from a party may form new parties (s. 62 of the OLIPPAC). In 2007 Dr Allan Marat, formerly the leader of People's Progress Party, after being expelled from the party, formed the Melanesian Liberal Party and was re-elected. The Rural Development Party of Moses Maladina (who was expelled from the People's Action Party), and the PNG Conservative Party of Hami Yawari provide examples of one-man parties formed to contest the 2007 election. This is another aspect of the OLIPPAC that needs to be reviewed.

\section{Conclusion}

The campaigns undertaken by parties in 2007 were intense but low key; this was probably due to the introduction of limited preferential voting. The bigger parties took the need to attract support seriously, and contested among themselves. But the time has come for parties to take another step by allowing 
party leaders to debate their policies in public forums. This would allow people to make informed decisions about whom to support. The majority of voters in Papua New Guinea are 'undecided voters'; they respond to the offer of material goods from the candidates. If this can be replaced by a focus on the policies of parties then elections might produce better outcomes.

The OLIPPAC was clearly observed in the formal requirements concerning endorsed and non-endorsed candidates and in the formation of government. ${ }^{8}$ But arguably the OLIPPAC has done little to strengthen the party system. There is still a large number of very small parties, most of which lack organization, funding, a coherent policy platform and mass support. Independent candidates still play a major role in the formation of government, and 'undercover' candidates make a mockery of the requirement that parties endorse only one candidate per electorate. Women's participation as candidates in the election, and more especially as elected MPs in the parliament, is minimal. There is a serious need to revisit the OLIPPAC to find ways in which the legislation may further strengthen the party system in the country.

Despite the fact that parties have become part of the political landscape in Papua New Guinea, there is no meaningful relationship between them and the voters. This has led to suggestions that the number of political parties in Papua New Guinea should be limited, to make parties more meaningful.

One suggestion is to tie parties to specific interests in society, such as class or workers' interests, gender, youth, farmers' or landowner interests, and so forth. This would enable the parties to develop coherent policies to cater for the interests that they represent. A party that does not represent any broad interests could be deregistered.

A second alternative is set a minimum number of votes to be received during the election (identified by the Electoral Commission) and any party that fails to reach the cut-off point would be deregistered. If any of its candidates win a seat, they would be asked to join one of the larger parties.

A third alternative is to set a minimum number of seats and deregister any party going below than the required number.

The provisions for deregistration of parties would have to be incorporated into the OLIPPAC.

Any of the above options would decrease the number of parties and make the parties stronger in terms of membership both in parliament and outside it, encouraging parties to provide the vital link between themselves and the people.

8 More than 12 months after the election, however, not one party had submitted the statement of contributions and expenditures required under the OLIPPAC. 


\section{References}

Anere, R., 2000. 'Political parties and elections in Papua New Guinea', in M. Rynkiewich and R. Seib, Politics in Papua New Guinea: Continuities, Changes and Challenges, Point No 24. Goroka: Melanesian Institute, pp. 120-144.

Gelu, A., 2007. 'Players in forming the government', Post-Courier 15 August 2007.

Hegarty, D., 1979. 'The political parties', in A. Amarshi, K. Good and R. Mortimer (eds), Development and Dependency: The Political Economy of Papua New Guinea. Melbourne: Oxford University Press, pp. 187-204.

King, P., 1989. 'Parties and outcomes in the 1982 election', in P. King (ed.), Pangu Returns to Power: The 1982 Elections in Papua New Guinea. Political and Social Change Monograph 9. Canberra: Department of Political and Social Change, Research School of Pacific and Asian Studies, The Australian National University, pp. 1-26.

May, R. J., 1984. 'Class, ethnicity, regionalism and political parties', in R. J. May (ed.), Social Stratification in Papua New Guinea. Working Paper No. 5, Canberra: Department of Political and Social Change, Research School of Pacific Studies, The Australian National University, reprinted in R. J. May (ed.) 2004. State and Society in Papua New Guinea: The First Twenty-five Years. Canberra: ANU E Press, pp. 127-146.

May, R. J., 2002. 'Election 1997: an overview', in R. J. May and R. Anere (eds), Maintaining Democracy: The 1997 Elections in Papua New Guinea. Port Moresby: Department of Political Science, University of Papua New Guinea and State, Society and Governance Melanesian Project, The Australian National University.

May, R. J., 2006. 'Political parties in Papua New Guinea', in R. Rich (ed.), Political Parties in the Pacific Islands. Canberra: Pandanus Books, pp. 83-102.

Okole, H., 2006. 'The fluid party system of Papua New Guinea', in J. Fraenkel and B. Grofman (eds), Political Culture, Representation and Electoral Systems in the Pacific Islands. Special Issue of Commonwealth and Comparative Politics 43(3):362-381.

Pok, E. and Winn, T., 2007. 'Independents and the law', Post-Courier 22 August 2007.

Reilly, B., 1999. 'Party politics in Papua New Guinea: a deviant case?', Pacific Affairs 72(2):225-246. 
Election 2007: The Shift to Limited Preferential Voting in Papua New Guinea

Stephen, D., 1972. A History of Political Parties in Papua New Guinea. Melbourne: Lansdowne Press.

Wolfers, E. P., 1972. 'A short history of political party activity in Papua New Guinea', in M. W. Ward (ed.), The Politics of Melanesia. Canberra: University of Papua and New Guinea and Research School of Pacific Studies, The Australian National University, pp. 439-488. 